\title{
THE SCARLET BEAT: THE EVOLUTION OF LAW ENFORCEMENT AT RUTGERS
}

\author{
BY MATTHEW KNOBLAUCH \\ matthew.knoblauch@gmail.com
}

The story of law enforcement on college campuses has often been a story of agencies that share dual roles-aligned with police and with student residence life-and struggle to maintain the responsibilities, often mutually exclusive, of both spheres. These agencies must perform their duties while they seemingly exist neither completely in the world of police nor in that of student residence. Although the agencies that patrol colleges and universities today are much more professional than those of the past, the officers in many retain the reputation of not being "real cops." These agencies have struggled against university administrators in determining the needs of a college campus, as well as the views held by the public, to professionalize and overcome the stigma of being associated with a college campus.

The history of the Rutgers University Police Department (RUPD) is a story that fits that mold of a campus security force that evolved out of a parking authority and became a law enforcement agency with full police powers. Before the RUPD was formed, the security of the campus was entrusted to residence life and administrative officials; parking was a matter for the building and grounds department of each campus. RUPD began as an organization that functioned in loco parentis, as did colleges more generally. Over time, however, founding director Robert F. Ochs transformed the department, from its creation in 1963, into a professional law enforcement agency. The term "professional" is not used here to signify a concrete set of standards and definitions but rather a nebulous perception that the public and other law enforcement agencies hold about the department.

The story of the RUPD was not that of a simple evolution; rather, the department faced conflicting imperatives. On one side, 
academic administrators pushed the department's in loco parentis role; on the other, Ochs wanted to balance the department's responsibilities to the students with a drive to professionalize the department as a provider of law enforcement that met the needs of a modern university. This dichotomy resulted in an organization that was initially unsure of its own role on campus, but it would eventually find its path and become a professional law enforcement organization that catered to a very specific population-college students - in addition to its regular duties as a police department.

This article examines the RUPD's evolution thematically to see how the department has professionalized as it has changed over time. First it establishes the need for a law enforcement agency on the Rutgers campus. The sections that follow evaluate the RUPD's professionalization, detailing the officers of the Campus Patrol/ RUPD and their retention rate, the administrative structure of the department, the evolution of officers' uniforms, and, finally, their acquisition of firearms.

\section{The Need for Law Enforcement}

What can be considered law enforcement specific to Rutgers began in the form of in loco parentis service. The tradition of students' being supervised by professors and other academics was common among colleges and universities in the United States during the first half of the 20th century. Before then, the faculty and administration of Rutgers typically "limited itself entirely to academic means, with the only extension being a compulsory chapel attendance twice daily." Until the mid-20th century Rutgers was a small, Ivy League-like college that did not need a large law enforcement organization because there simply was not a large number of people on campus. Walter Carl Heyer, of the Rutgers College class of 1925, remembered how small Rutgers College truly had been, saying, "[When] we graduated, our whole class ... was ... 148." Other alumni described the atmosphere of Rutgers College in those days as being different from that of the present because of its small size and close-knit environment. "Well, the college was so small that, you know, everybody knew everybody and so forth. You felt a part of something, and that I think makes a big difference. Today a man goes to college, and I don't know whether there's much college spirit or not-maybe there is. But I'm not around to find out really for sure. But it's too big for that today." When the student body doubled from 1906 to 1916, it only grew from 236 students to $537 .{ }^{1}$ 
The Rutgers campus was easily managed during the early 20th century because there were only a few dormitories. Winants Hall, the first dorm, was built in 1890, followed by Ford Hall in 1915 and the Hegeman-Wessels Quad in the late 1920s. Before this time, students often boarded with New Brunswick locals or occasionally lived in less-than-usual locales, such as aboard a boat docked on the Raritan River. If a crime occurred, New Brunswick Police would render service. The creation of dormitories on college campuses changed the college way of life by bringing college officials into the nonacademic portions of students' lives. ${ }^{2}$

After World War II, changes at Rutgers and in the United States prompted a massive expansion. Returning veterans, funded by the G.I. Bill, attended colleges in greater numbers than ever before, and Rutgers was no exception. As more students began to live in dorms, student life became a way of life. Before 1900, the faculty and administration were concerned only with a student's scholarly pursuits. By the 1960s, a trend was observed in academia "away from merely providing 'something to study' to providing an entire way of life, where students are under University supervision from September of the freshman year until the June of graduation." ${ }^{3}$

This massive influx of students combined with a postwar automobile culture to create a parking problem on the Rutgers campus. Americans were moving to the suburbs from the cities, and they needed automobiles to get them to work and, in some cases, to college. Between 1950 and 1970, the population of Americans living in the suburbs doubled, from 36 million to 74 million. This led to a similar increase in automobile traffic. The Rutgers community became acutely aware of this problem as it grew, so much so that "in 1961, Robert Heller and Associates were employed to conduct a survey of the parking problem at the New Brunswick Campuses of the University. Their report to the Board of Governors was rendered on April 10, 1961, and consisted of recommendations for a parking program designed to meet present and future parking requirements to $1970 . " 4$

The parking problem at Rutgers had been recognized by university officials as "one of the toughest problems for both the City [New Brunswick] and the University to solve." In response to student concerns about parking, in November 1949 Rutgers provost Mason W. Gross called for a special committee of three faculty members to investigate parking. At the time, Rutgers had residential facilities for only a third of its student body, now numbering about 
3,800 . Further, a restriction on automobiles was not feasible due to the large commuter population. In planning to meet the parking needs of Rutgers, Gross attempted to work cooperatively with the Johnson \& Johnson company, which was headquartered adjacent to Rutgers College in New Brunswick. ${ }^{5}$

Administrators at Rutgers chose to handle the traffic problem by registering all vehicles whose owners were affiliated with the university. The registration was simple; each car received a decal in one of three colors: white for faculty and staff, red for the QueensNeilson area, and blue for the Bishop-College Park area. And each car could be parked only in the parking area designated by the decal on school days. Of course there were fines associated with a violation of this policy. Failure or refusal to register a vehicle after a warning resulted in a $\$ 5$ fine, parking out of an assigned area between 8 a.m. and 5 p.m. on weekdays cost $\$ 1$, and parking in a no-parking area, such as a driveway, gateway, or corridor resulted in a $\$ 2$ fine. At this time, in January 1952, it was the responsibility of the Buildings and Grounds Department at Rutgers to issue tickets and collect fines. ${ }^{6}$

Unfortunately for the motorists of Rutgers, the parking problem was not solved in the 1950s, just as some people say it is not solved today. In September 1957, the Rutgers community grew concerned about the surplus of cars and the associated hazards for parking, vehicular traffic, and pedestrian traffic. As part of its 1961 evaluation and report, Robert Heller and Associates forwarded 13 recommendations. To facilitate their implementation and to ease the problems encountered by the existing campus bus system, the Department of Campus Parking and Transportation was created on July 1,1961 , headed by Robert F. Ochs. ${ }^{7}$

Ochs was not new to Rutgers. He had been born in New Brunswick in 1923 and gone to Rutgers College. In 1942, after a brief time at college, he had enlisted in the Marine Corps and served in the Pacific during World War II. Upon his return from combat, he had come back to Rutgers and continued to play football, as he had before he left. In reference to his service, Ochs said, "the Marine Corps molded my way of life. If it hadn't come along, I don't know what my life would have been like." ${ }^{8}$

Ochs graduated from Rutgers and held several jobs in the 10year period afterwards. In 1958 he was hired by Rutgers in a fundraising program for the College of Engineering. Ochs learned about a parking program during a presentation, and, he says, "About 
two days later, Dr. Gross calls me up, and says, 'Bob, I want you to take this on." But Ochs was no parking expert and recalls saying, in response to Mason Gross's request, "Doc, all I knew was how to park a car. I didn't know anything about parking." So, on Gross's suggestion, he visited some schools, including the University of Michigan, the University of Illinois at Urbana-Champaign, and Ohio State, and came back to become the director of the new Department of Parking and Transportation in 1961. In 1963, Gross asked Ochs to create an unarmed security force that would patrol parking lots and other areas of campus out of the parking department. The Department of Campus Parking, Security, and Transportation was established on September 1, 1963, and was referred to as Campus Patrol. ${ }^{?}$

\section{The Administrative Structure of the Department}

The professionalization of Campus Patrol as it evolved into the RUPD, from an unarmed security force to an armed police department, can be measured by the changes that occurred in the administrative structure of the department, its authority and jurisdiction, the incidence of crimes, and the number of personnel. The department's authority and jurisdiction not only increased but were also more widely recognized by neighboring agencies. Campus crime rates increased overall for a period of time but then began to decrease by the 1980s, although the overall number of noncrime incidents increased. The department's roster also greatly increased over its 50 years of existence.

Soon after Campus Patrol's inception on November 18, 1963, at 12:01 a.m., the department began operating 24 hours a day, seven days a week, 365 days a year. It was primarily concerned with "parking and traffic control, the security of the physical plant and all associated with the University, the prevention of accidents and crime, the investigation and factual preparation of reports, and the development of an efficient inter-campus transportation program." Physical plant security had formerly been under the direction of each college's department of buildings and grounds. Campus Patrol's early administrative structure was a simple continuation of the structure that had been in place during the two years in which it had been only a parking authority. Ochs was still director, but now other employees joined the department's ranks. The department was a "seven-man force of uniformed parking officers, operating four radio patrol cars, [which was] augmented by the 
22 security men and nightwatchmen who protect the downtown, Douglass, agricultural college and University Heights campuses." Effective on "January 1, 1964, Campus Patrol 'inherited' all University watchmen who had previously reported to various plant supervisors." Before Campus Patrol was created, the university's lone "policeman" had been George Lambert, a former New Jersey state trooper who had served as a proctor on the dean of men's staff. ${ }^{10}$

Each Campus Patrol employee had a 40-hour work week except for two secretaries, and all were uniformed except for administrative staff. Operationally, Campus Patrol was broken up into four squads, Squad A-Squad D. Each squad had a sergeant and three patrolmen in cars. The sergeant remained at Campus Patrol Headquarters, at 261/2 Morrell Street in New Brunswick, while each of the cars, numbered 2-4, was assigned to a campus. Car 2 was assigned to the College Avenue Campus, Car 3 to the DouglassAgricultural Campuses, and Car 4 to the University Heights-Raritan Campuses. Additionally, there were security guards on foot or on scooters on each campus and a traffic-parking squad that operated during the day. All of these personnel and the two clerical workers fell under the command of a security officer, John Massei, who was a "trained and experienced law enforcement officer," and was, in turn, under the command of Ochs as director. By late August 1964, the four security squads were placed on a 28-day rotating shift cycle; a patrolman would work seven days on first shift, have four days off, then work seven days on third shift, have two days off, work seven days on second shift, and then have one day off before the cycle repeated. During its first year of existence, from November 18, 1963 to December 31, 1964, Campus Patrol handled 3,942 incidents. Many of these took the form of assists to students, staff, or faculty, such as opening doors, but others were more serious, such as handling 284 larcenies, one rape, 13 stolen motor vehicles, 26 missing persons, one suicide, and two alleged shootings. ${ }^{11}$

The department was merely a security force at this time, and because of this it was looked down upon by neighboring police departments. However, because Campus Patrol enforced rules and regulations that police enforced in a municipality, the department was an entity that crossed the boundary between student residence life and law enforcement. The New Brunswick Police Department observed this boundary crossing and criticized Campus Patrol for it. In November 1964, a Franklin Township female minor was 
drinking alcohol at the Beta Theta Phi fraternity on Union Street in New Brunswick when she was injured in a fall. Ochs personally took the call and was criticized by the New Brunswick Police Department for not calling their department in a timely fashion. The New Brunswick Police Department felt that Campus Patrol was just a security force whose responsibility ended at the borders of the Rutgers campus; in responding to this call for help off campus, Campus Patrol had overstepped their bounds into the zone of professional law enforcement. ${ }^{12}$

The university itself observed the campus boundaries as the lines for discipline. After a three-month study conducted by "an Ad Hoc Committee on Student Rights and Responsibilities" in 1965, the university decided that it would not take disciplinary action on off-campus offenses committed by students. This decision set a precedent that Rutgers would observe these boundaries. It certainly did not aid Campus Patrol in any attempts they might make to legitimize their authority by extending it across the bounds of campus into neighboring communities. Their beat was Rutgers and only Rutgers, which reflected the college's belief in in loco parentis. ${ }^{13}$

Campus Patrol had authority only on campus, but other police agencies came to campus to make arrests when need be. In 1968, "a State Police narcotics investigator, who was assisted by New Brunswick Police, arrested two University students on campus." Campus Patrol did not yet have the authority to make arrests, so local or state authorities would intervene in these scenarios. If any more serious crimes occurred on campus, from car thefts to assaults or worse, the local police came to campus. ${ }^{14}$

The department saw changes that were largely in the direction of its becoming a true law enforcement agency as it grew throughout the 1960s. Campus Patrol responded to an everincreasing number of incidents. Mazzei, the department's security officer, had been promoted to assistant director in 1966 and became the first chief of the department in 1967. Michael Borden was hired on September 6, 1966, as a lieutenant and was promoted to captain on July 1, 1967, and chief in 1968; he had previously been an officer of the Highland Park Police Department for 16 years. In 1967, Ochs was promoted from director of the department to assistant to the vice president and treasurer. The department's headquarters moved to 3 Bartlett Street in August 1965 and would later move to 5 Huntington Street. Security guards were given posts on the Newark and Camden campuses of Rutgers as well. 
On February 14, 1966, Campus Patrol assumed full control of the security of Rutgers-Camden, with a New Brunswick-trained patrol sergeant transferring there in August 1966. On July 1, 1966, a New Brunswick-trained sergeant was transferred to the Newark campus and supervised guards contracted through the Quick Agency. Additionally, Livingston College opened in September of 1969, becoming another area that needed to be patrolled on the New Brunswick and Piscataway campuses. ${ }^{15}$

A new era for Rutgers and Campus Patrol began on September 1, 1971, when President Mason Gross retired after 25 years of service to the university. Gross's belief had been that the function of Campus Patrol was to act in loco parentis. In this new era of student activism, the creation of a new type of agency was necessary, and a new president would make that happen. ${ }^{16}$

The department continued the trend of meeting the university's needs by shifting out of in loco parentis and into the world of law enforcement. Rutgers itself was becoming increasingly larger; in 1960 there were 18,255 students, in 1970 there were 34,015, and by 1980 the student population had reached 48,444. By 1974, Rutgers Police in New Brunswick had 89 sworn officers. Ochs had now become assistant vice president of public safety. In 1970, all new Campus Patrol uniformed personnel were required to be trained at the New Jersey State Police-sponsored Police School in Sea Girt, New Jersey. Campus Patrol responded to 15,424 incidents in 1970 compared to 4,974 total incidents in 1965. According to the 1970 Annual Report published by Campus Patrol, "More and more reports were received of weapons being used in crimes against persons." Perhaps the most significant change in the history of the department until that time was the passage of chapter 211 of the New Jersey Laws of 1970, authorizing the granting of full police powers to institutions of higher learning, including Campus Patrol. Through this law, campus officers were eventually allowed to carry weapons on all regular shifts, an issue that will be discussed later. ${ }^{17}$

Even toward of the end of the first 10 years of the department's existence, Campus Patrol still had other police agencies operating on campus, sometimes without notifying the department. On April 29, 1971, Piscataway Police arrested six students at Davidson Residence Hall for the use of marijuana. According to the chief of Campus Patrol, Michael Borden, it was not a legal requirement for outside police departments to notify Rutgers when they came onto 
campus, although they ordinarily did so. By the 1980s that would change as the department's reputation caused it to be more highly respected by neighboring police departments. ${ }^{18}$

In 1975, the university authorized a name change from Campus Patrol to the Rutgers University Police Department, and the department was a part of the Division of Public Safety, which included the University Police Department, University Parking Department, University Fire Department, University Safety Office, University Radiation Safety Department, and Inter-Campus Bus Program. The Division of Public Safety was still headed by Ochs under the university's senior vice president and treasurer, Joseph C. O'Connell. At this time, the RUPD in Camden and Newark was supervised by two captains, Robert C. Wyzykowski in Camden and James L. Rhodes in Newark. By 1978, the continued growth of the department was evidenced by the expansion in the structure of the department. The RUPD in Camden was led by Deputy Chief Andrew Byrd and in Newark by Deputy Chief James Rhodes; their position was no longer that of a captain. In the RUPD in New Brunswick, Thomas M. Thompson was chief in 1979; Robert D. Bunker remained as assistant chief; there were three captains, one for operations, one for the uniform division, and one for detectives, as well as four lieutenants. The continued growth of the department as a whole was clearly visible, in its scope and on the organizational chart, when compared to that of only a few years before. ${ }^{19}$

The 1980s were far less eventful than the 1970s in terms of changes to the structure or operations of the RUPD. From 1979 to 1983, although the overall number of incidents increased, the number of crimes went down; that trend continued for the remainder of the 1980s, reflecting a wider trend nationally. Between July 1979 and June 1980 there were 1,339 crimes, ranging from arson to larceny to rape to robbery, while the period from July 1982 to June 1983 had only 875 total crimes. As it had been doing since 1970, the department continued to send its officers to police academy training courses approved by the New Jersey Police Training Commission, which included a 40-hour firearms course. By 1985 , the course had been increased to 85 hours. Officers could qualify on a shotgun in addition to their duty weapon. All officers were still required to qualify with their firearm twice per year, as they had been required to do since being qualified by the Police Training Commission. But that firearm was still the property of the department, and officers could not carry their weapon off-duty. ${ }^{20}$ 
In 1984, the RUPD created a Crime Prevention Program to improve the total security of the university. By this time, the rank structure consisted of a chief, four captains, five lieutenants, four detectives, and seven sergeants for the New Brunswick and Piscataway campuses. By 1985, all three Rutgers campuses had their own RUPD chiefs. Further, neighboring police departments had come to respect the RUPD. If a crime occurred on the Rutgers campus, it was investigated by Rutgers police without outside help. ${ }^{21}$

On March 1, 1988, Leslie Scoville, the former director of campus safety at the Rochester Institute of Technology in New York, was hired as assistant vice president for public safety after Ochs's retirement. Ochs had taken the department from a parking authority to a professional law enforcement agency without sacrificing the core values of a college police department: service to the students. Ochs understood what it meant to be a college police department and understood the value of in loco parentis, which he felt gave university officials the ability to handle disruptive students in a more appropriate manner. Ochs, making reference to a conversation with a student who had apparently made some sort of mistake, said:

More than once, I'd have a kid, a good kid, who had done some damn fool thing. Okay? Rather serious, but damn fool. I said, "Now look, Charlie, I admit that I am a bullshitter, but enjoy listening to a professional, and that's what you are. So what I'm going to do, here is your father's number, I'm just going to call up dad and ask him if we can meet him for supper tonight." "Wait! Wait!" Man, what power it had to resolve the issue. Dad didn't get involved, but I would have gotten dad involved if necessary. ${ }^{22}$

Ochs felt that provost Richard Schlatter's announcement that Rutgers would no longer serve in loco parentis "weakened the university's whole position." Yet, at the same time, he was not afraid to use force because he understood the demands of a law enforcement agency. When a potentially violent "rabble-rouser" came to campus, Ochs "had about 300 cops stacked up," and "the only people that knew it [were] the treasurer and the president" because he "had to bill them for services." He had begun his career under Mason Gross and had continued almost to the end of Edward Bloustein's administration. He had observed the more old-fashioned ways of 
enforcing discipline on campus and kept those ways as a moral compass as he professionalized the police department by bringing its operations more in line with those of municipal police agencies. Under Ochs's leadership, Rutgers Campus Patrol had evolved into the RUPD; it had gotten the use of firearms on all tours, the powers of arrest, and uniforms that officers felt they could wear with pride. ${ }^{23}$

The administration of Scoville, later Fehrenbach, was one that continued the trend of professionalization that Ochs had started 25 years prior. The RUPD continued to provide excellent service as it responded to crimes and other calls for assistance by advancing technologically and continuing to be excellent leaders.

On November 3, 1993, less than a month after Chief Anthony Murphy assumed control of the RUPD following the retirement of Chief Thomas Thompson, a Cook College student was shot outside of her Newell apartment as she walked home. She was taken to Robert Wood Johnson Hospital where her condition was stabilized. Shortly after, three suspects were arrested by North Brunswick Police. The assailants were not affiliated with Rutgers; regardless, the crime shocked the Rutgers community. Safety meetings were held, and students, faculty, and staff alike were genuinely scared. The idea was even posed that the campus be closed off with a physical barrier, but both Murphy and Scoville agreed that the measure would be impractical. ${ }^{24}$

While a shooting was unique on the Rutgers campus, crime more generally was not. In February 1992, the RUPD arrested six current and former students who were suspected of 15 burglaries at 11 campus buildings on Busch Campus, which totaled $\$ 20,000$ in goods stolen. In March 1992, in response to safety concerns associated with sexual and other assaults, the RUPD and the larger Rutgers community acted to make the campus a safer place. By April, there were a reported nine sexual assaults on the Rutgers-New Brunswick campus. Scoville said, "I'm continuing to talk to students and student groups to get their feedback, and we will be evaluating the recommendations we have received so far," in reference to campus safety. To make the physical plant safer, campus lighting was improved and obstructive bushes were cut. Also, acquaintance rape education programs were made mandatory for incoming students and blue-light telephones (emergency phones that have a direct line to RUPD) were added on campus. RUPD and the larger university community had begun to be proactive in trying to prevent these types of crimes. ${ }^{25}$ 
The RUPD continued to advance technologically while it professionalized by being more transparent in its reporting. By early 1993, the RUPD, along with the rest of Middlesex County, was included in the new 911 emergency phone system. This new system was a much more rapid and organized police dispatch and response system than anything that had existed before. Innovation and advancement had secured the RUPD's position as firmly within the world of professional law enforcement. In 1992, in compliance with the Student Right-to-Know and Campus Security Act, Rutgers Police published a crime statistics report for public consumption, called Safety Matters. Although the RUPD had been providing these statistics to the FBI for its Uniform Crime Report since 1972, this act made students more aware of crime on the campus. According to the data published in a report by a lobbying group called Security on Campus Inc., "Rutgers is not alone in its increased awareness of the problems of security on campus. Schools across the country are also grappling with these problems-from large, urban schools like Rutgers, to smaller schools located in rural areas." The Targum reported, "According to the 1991 FBI Uniform Crime Report, the schools with highest overall crime rates were large state universities with student populations larger or roughly the same size as Rutgers. Michigan State University in East Lansing, Michigan, with an enrollment of 44,307 students, had 62 incidents of violent crime" in 1991, while Rutgers-New Brunswick had 23 incidents of violent crime with 33,016 students. ${ }^{26}$

The department would continue to respond to serious crimes committed both on and off campus. On April 4, 1995, a bomb exploded in the Mabel Smith Douglass Library. The event led to an evacuation of all 13 libraries on the New Brunswick campuses, but no injuries occurred. The bomb caused minimal damage, but the issue was not taken lightly. It received a response from the New Jersey State Police; the Bureau of Alcohol, Tobacco, and Firearms; the Federal Bureau of Investigation; and other agencies. Fehrenbach suspected that "it was placed there for a particular reason and ... not to hurt anybody." Less than a week later, a second bomb was discovered at the Douglass Library. The series of bombs, bomb discoveries, and bomb threats that plagued the Rutgers community left many with a feeling of unease. ${ }^{27}$

In response to the national tragedy that occurred on September 11, 2001, five RUPD officers assisted in the search and rescue efforts in New York City on September 12. The five officers, 
Sergeant James Fischer, Lieutenant Stanley Kosinski, Officer Sean Skala, Officer Deron Ilarraza, and Officer Jason Farella, were among a group of 128 officers sent from various Middlesex County police departments. The officers spent 14 hours at Ground Zero assisting with rescue and recovery efforts. ${ }^{28}$

In the 2000s, the RUPD underwent a few changes in leadership. Jay Kohl, a former police officer, police chief, and public safety director from the Midwest, was hired in 1999 as executive director of public safety under Fehrenbach, now associate vice president of administration and public safety. In 2002, Fehrenbach became associate vice president of administration and then, in 2003, was hired as the secretary of the Board of Governors, which left Kohl in charge of the Department of Public Safety. In May 2003, Barry Roberson was named chief of the department after the retirement of Anthony Murphy. Roberson was a former lieutenant colonel with the New Jersey State Police. But in 2005 Roberson left Rutgers to take over as director of public safety in East Brunswick, and Rhonda Harris, a 17-year veteran of the RUPD, was named chief of the 127-member department. At the time, she was one of five female police chiefs in New Jersey. ${ }^{29}$

In October 2001, the RUPD sent its first crime alert through the student email system, called Eden. The idea that crime alerts could be sent via email marked a technological revolution at Rutgers. Now students would be aware of all crimes that occurred on campus. Students who were more informed could take actions to make themselves safer on campus, which was a goal of the new crime alert system. ${ }^{30}$

The first few years of the decade were also a time of physical advancement for the department. The university had finally responded to the fact that the department had outgrown its twostory headquarters on Huntington Street. In December 2001, senior vice president and treasurer JoAnne Jackson "unveiled plans for a new public safety complex in ... downtown New Brunswick." The new complex would be located at the intersection of George Street and Commercial Avenue and would signify the move of the police department from 5 Huntington Street. The construction of the building took about five years, and by the summer of 2006 the RUPD had moved into its new headquarters at 55 Commercial Avenue. The Public Safety Building would also serve as the headquarters of the Department of Emergency Services and the Department of Parking and Transportation. This was the first time 
that the department's headquarters were built specifically for a law enforcement agency. The old buildings were retrofitted houses; this structure was built with law enforcement in mind. It dwarfed the old headquarters and gave the department more space than it had ever had in the past. ${ }^{31}$

In another proactive safety measure undertaken by Rutgers Public Safety, cameras were placed on campus. Professors who had been present during the Vietnam War-era protests on campus were wary of the idea of "Big Brother" watching them. But, as it turned out, students were accustomed to technology intruding on their everyday lives and had no qualms with the installation of cameras in public areas. By the beginning of the 2010s, there were more than 2,000 cameras operating on the Rutgers-New Brunswick and Piscataway campuses that, as the signs denote, were installed for safety. ${ }^{32}$

The RUPD and Public Safety advanced and streamlined considerably in the 21 st century. Public Safety was brought into a more organized structure in which each department had more communication, which led to better interaction. Further, the heads of all departments within Public Safety began meeting weekly to ensure adequate communication within Public Safety. Shortly after Kohl was hired by Rutgers, he oversaw the creation of a program for better interaction between the RUPD and the community it served: students. The Community Service Officer (CSO) program employed students, in uniform, to serve as the eyes and ears of the RUPD. These students received 40 hours of training and represented an advancement in community policing. Students were the community that the RUPD served, so, according to Kohl, there was no better way to have a positive relationship with the community than to bring the community into the department. Student marshals and other student patrols had existed in the past, but the CSOs had a fundamentally different flavor; they were part of the police department. Past student programs had not been part of the police department, and although they aided the RUPD in operations, they did not bring the student community into the police department, as the CSOs did. ${ }^{33}$

In another regard, RUPD and Public Safety began to respond to issues of legal liability. After events such as the tragic Seton Hall University dormitory fire in 2000, Public Safety at Rutgers increased its preventative measures for fire protection and crime prevention. At the time of the Seton Hall fire, only 37 percent of Rutgers dorms 
had proper fire sprinklers. By July 2003 , the $\$ 40,000$ project to retrofit Rutgers' sprinklers was 78 percent complete. Further, the RUPD took proactive measures for ensuring the survival of their own officers and the survival of victims in fires. Kohl, who had experience combining fire and police departments, suggested a measure that would provide a 16-hour training course for police officers to learn the basics of fire rescue and survival training. This training was conducted in the classroom and at the fire training grounds of Middlesex County Fire Academy. ${ }^{34}$

Continued training was another domain in which the department excelled. In the early 2000s, the RUPD and other agencies of Public Safety, as well as the U.S. Army, Middlesex County SWAT, and other law enforcement and emergency service agencies, organized a number of drills to practice and assess their procedures and skills in response to large-scale incidents. The training incidents included mock explosions on campus and hostage situations. The colossal effort put forth in training the officers of the RUPD demonstrated the department's commitment to creating and maintaining a highly skilled police force. ${ }^{35}$

A college police department has a unique responsibility to students. For college police departments, the students are their community, but undergraduate students are young, and most are on their own for the first time. This newfound independence requires a kind of supervision that is by nature more parental than that of a municipal police department. In response to the growing frequency of sexual assaults and other crimes on campus during the 1990s and 2000s, the university as a whole responded with the creation of the Office for Violence Prevention and Victim Assistance as well as the Center on Violence against Women and Children. Further, in 2010 Rutgers faced a great tragedy with the suicide of Tyler Clementi, a student who was cyber-bullied by his roommate over his sexual orientation. This incident prompted a local, state, and national response to concerns over cyber-bullying and particularly the difficulties faced by LGBTQ adolescents. The RUPD responded to these events as well, creating specific policies within its standard operating guidelines so that officers know how best to handle a situation such as the one faced by Clementi. ${ }^{36}$

In 2011, Kenneth Cop was promoted to chief after Harris retired from the RUPD to become the public safety director at Old Dominion University in Virginia. Additionally, in 2011 the RUPD received Commission on Accreditation for Law Enforcement 
Agencies (CALEA) accreditation-"the gold standard in public safety." This was no easy task for the department. "Achieving accreditation represents the completion of a three-year departmentwide period of self-evaluation which concluded with a thorough review by a team of independent assessors." Officers and administrators alike worked to ensure that the RUPD "met or exceeded 479 standards established by CALEA and accepted by the international law enforcement community as best practices." This accreditation meant that the RUPD was an internationally recognized law enforcement agency that unequivocally demonstrated excellence in its operations. ${ }^{37}$

The changes and enhancements to the administrative structure of the Campus Patrol as it transformed into the RUPD demonstrated its professionalization. Officers increased in numbers and became better trained, the department's administrators received more responsibilities as they moved through the university's bureaucratic ranks, its authority increased as it became a law enforcement agency, and its jurisdiction increased as neighboring police departments came to respect its authority.

\section{Officers and Officer Retention}

The staple of any law enforcement agency is its rank and file, in Rutgers' case the patrolmen of Campus Patrol and officers of the RUPD. Although the department's improvements continued the trend of professionalization, it suffered from a high officer turnover rate, which was attributed to a poor public image, the prohibition against carrying firearms, and relatively low salaries. As the perception of campus police was transformed and as officers received the right to use firearms, the department progressed. Officers diversified in both abilities and demographics; female officers and officers of underrepresented ethnicities, in law enforcement and more generally, were hired, and officers were trained on horseback. Relatively low salaries would remain an issue and a source of officer attrition. Ultimately, the officers of the RUPD continued to professionalize over the course of the department's history.

At the outset of the department's creation, a high turnover rate was experienced. Ochs, however, did "not anticipate a personnel turn-over such as that experienced during the department's initial months." Ochs had great faith in the dedication of his employees, stating that "with the possibility of one or two 
exceptions, Campus Patrol personnel are dedicated employees who have placed their future with the University." Ochs recognized Campus Patrol's role as an authority and wanted trained officers under his command. He was an experienced marine and knew the value of training. Campus Patrol set up 15-week training programs for this purpose. ${ }^{38}$

Although Ochs was optimistic about the future of his department, it was apparent that his patrolmen were less so. The high turnover rate could be attributed to a couple of factors. Campus Patrol personnel were campus patrolmen and not "real cops." These employees, if interested in careers in law enforcement, would doubtlessly trade in their jobs at Campus Patrol for ones at a police department that granted their officers the power of arrest and the use of firearms. Ochs felt that campus patrolmen should "enjoy the powers of arrest," but he made clear his distinction between campus patrolmen and municipal police officers. Ochs took his job very seriously, often patrolling the campus personally, and he expected the same seriousness from his personnel. But they were not police officers at this time, nor did he envision them that way. ${ }^{39}$

The issue of officer salaries in relation to officer retention did not go away during the department's early years in response to Ochs's more aggressive training initiatives. In regard to the increase in incidents over time, the 1966 Annual Report for the department stated:

It must be noted in passing that Campus Patrol can only continue to meet the needs and demands of the University by being competitive with those municipal police departments with whom it is in competition when recruiting personnel. Campus Patrol employees must have salary and benefits equal to, or better than, those of the best area police department if it is to maintain the caliber of man providing the service the University currently enjoys.

Again in 1968, pay raises were cited as "instrumental in retaining and attracting high caliber personnel. The continuance of maintaining competitive salaries and benefits, coupled with authority, should be instrumental in the retention of present personnel and make attractive the inducement to other needed employees of Campus Patrol." Ochs understood that the salaries of his officers must keep pace with those of officers in the surrounding 
municipalities if he was to have his choice of the best candidates for employment. ${ }^{40}$

Ochs predicted that "now that the Campus Patrol has 'come of age,' and with the improved salary scales effective last July [1965], these changes should not be so great in the future." Ochs was hopeful about the future of the department and realized that better training would lead to more professional campus patrolmen who took their jobs seriously. He knew that he needed to maintain that standard of professional training if the department was to improve. At the time, police school, which officers could attend in a variety of locations, was six weeks long. Ochs was not afraid to fire patrolmen if they did not meet his standards, stating that "terminations will be processed if the standards established for the department are not met after one or more warnings." In Ochs's high hopes for the department, he believed that "all Campus Patrol personnel desire to strive for excellence because they have placed their future and that of their family with the University." He saw their job as campus patrolmen as being professional, even though it was not a job in true law enforcement just yet. ${ }^{41}$

In 1972, the first three female officers joined the ranks of Campus Patrol; Ellen Nemeth, age 21, Lynn Engelhardt, age 23, and Monica Batiuk, age 27, were hired as University Police officers by October and attended classes at Middlesex County Police Academy in Edison, New Jersey. The new officers had responded to ads in the newspaper. Campus Patrol, as part of an academic community that had observed civil action and social justice riots and demonstrations, was aware of the importance of having a department that met the needs of a demographically diverse community. But there was a double standard for these female officers. Of course they would have the same responsibilities as any male officer, but, Ochs said, "They will not initially patrol in remote areas alone at night"; rather, "their assignments at first will be in the highly-populated areas where they will be involved with students." But, compared to what was seen in other law enforcement agencies of the era, hiring them was a progressive step. In 1972, only 1.5 percent of all sworn police officers nationwide were women, and even by 1981, that number had only changed to 5.5 percent. $^{42}$

In 1976, Campus Patrol, on all three campuses, had a total of 14 African American male officers, one African American female officer, six Hispanic male officers, no Hispanic female officers, 53 white male officers, and three white female officers. Within 
a few years, Campus Patrol had hired a number of officers from various demographics that were still largely underrepresented in law enforcement. In comparison, in 1968 only 5 percent of police officers in Detroit, Michigan, were African American, even though Detroit's population was heavily African American. ${ }^{43}$

Campus Patrol also led in another aspect of law enforcement. According to a 1973 New Brunswick Daily Home News article, "Rutgers officials believe that their school is the first in the country to use mounted patrols on campus." The article showed a mounted patrolman, Richard McGilvery, showing his horse to two children. Anyone who has ever encountered a mounted police officer can attest to the fact that they are a force to be reckoned with. The size of the beast was something most urban and suburban college students as well as New Brunswick locals certainly were not familiar with, and for crowd control, a mounted policeman "is as good as 10 men on the ground" according to New Brunswick Police director John T. O'Brien, a former New York City Police captain. Ochs not only considered the crowd control advantages of using officers on horseback, but he was also in favor of it because of a horse's ability to interact with people, saying, "I never saw anyone pet a police car on the nose." ${ }^{44}$

In October 1972, in reference to the salaries of the three recently hired female police officers, a Targum article reported that they "will get a starting salary of $\$ 7,812$ per year, which Ochs said 'is still not enough money." The article further reported, "Neighboring municipalities pay higher salaries to patrolmen. Rutgers is now in the process of getting the pay raised for all University Police officers." Ochs still understood the importance of a police officer's salary and continued to advocate for higher pay for his personnel. ${ }^{45}$

On Friday, October 6, 1978, McGilvery was accidentally shot and killed when his revolver fell out of its holster as he chased a suspect after a burglary in progress at the Jameson residence hall on the Douglass College campus. McGilvery had been an officer for the RUPD for seven years and was 35 years old. He died in the emergency room of Saint Peter's Hospital at approximately 11:40 p.m., about "an hour after a single bullet entered his lower right abdomen and pierced his right lung." McGilvery was the first and, up until the present day, only officer to die in the line of duty for the RUPD. Ochs said of McGilvery that he was an "excellent investigator" who was an "expert in photography and fingerprinting." He was one of the first three officers to become a 
mounted police officer and then had become a detective two years before this incident. His death was one of the saddest moments in the department's history. ${ }^{46}$

In spite of the progress the RUPD had made in increasing its structure and permitting officers to carry firearms while on duty, the Annual Report for 1985 stated that "turnover of personnel has continued to present problems in staffing. The need to constantly recruit qualified police officers and security guards seems to be an unending task which involves the time and efforts of all police and security commanders." This problem has persisted throughout the history of the RUPD and doubtlessly stems from the aforementioned problems: the image of the department as not being true law enforcement, the fact that officers still could not carry guns off-duty, and the relatively low salaries. ${ }^{47}$

Ochs personally did not feel that it was necessary for an officer to carry a firearm off-duty. He stated, "The position we've always taken is that a University Police officer is a unique and special law enforcement officer whose primary purpose is to protect the safety of the academic community." He added that the primary reason that officers had left the RUPD was "the level of salary, and we can demonstrate that." Between July 1, 1977, and June 30, 1979, the department had lost 17 commissioned officers to termination, transfer, retirement, resignations, and death. "Of these, 12 were commissioned Police Officers who resigned. They had been schooled at considerable cost to the University Police Department. Ten left to work for other Police agencies. One left to work in a different department within the University and one left for reasons that appeared to be incompatible with a police career." 48

The problem of salaries would persist throughout the 1980s and beyond, but the issue of firearms was resolved in 1991 when RUPD officers were allowed to carry firearms at all times. In March 1998, the officers of the department had gone three years without a contract. According to Detective Richard McIntyre, "Everyone is extremely frustrated at this point in time, due to the fact that we've been waiting more than three years." A Targum article on the subject noted that "many new officers come to Rutgers to gain experience, but quickly transfer to other police departments where they can earn more money." Officer Amy Hackett, the community police officer for Douglass, commented, "It seems like our department is the training department." The article further noted that highranking officers in the department made about $\$ 17,000$ less 
per year than similarly ranked officers in the Piscataway or New Brunswick Police Departments. Officers in the days of Campus Patrol were fully aware of the department's deficiency; however, the officers of the RUPD maintained their professionalism. Chief Murphy said that "he applauds the extremely professional response of the officers not to allow the frustration of negotiations to affect their performance." Rutgers police officers did not let chronic low salaries get in the way of their performance of duties. Inadequate compensation was one more problem the RUPD would need to overcome to completely relieve itself of the stigma of not being "real police." ${ }^{49}$

The misperception stemmed from the fact that the RUPD was, quite obviously, associated with a college campus and not a municipal government. The Targum reported, "The student perception of the Rutgers University Police Department ranges from thoughts that they aren't real cops to thoughts that they are state troopers." The fact that a college police department has a constantly changing population, as students enroll and graduate, meant that the RUPD stressed public education and a good relationship with the Rutgers community. Rutgers students had to constantly be educated about the nature of the RUPD, its relationship to the community, and its abilities. Neighboring police departments understood how far the RUPD had come from its days as a security force. The director of the New Brunswick Police Department, Michael Beltranena, noted that "the Rutgers University Police Department is progressive, well-trained, disciplined and pro-active and it serves not only the University, but has a strong relationship with the New Brunswick Police Department." Many students and nonaffiliated individuals would learn the hard way that the officers of the RUPD were "real cops" as they patrolled their jurisdiction in the municipalities of New Brunswick, Piscataway, Highland Park, Edison, North Brunswick, and East Brunswick. But, the RUPD had earned its good reputation among police departments in neighboring townships with the dedicated and professional service of its officers. Both RUPD officers and officers in neighboring townships, such as retired Piscataway Police lieutenant Amy Myzie and retired RUPD lieutenant Peter Pelletier, viewed the officers as some of the most capable individuals in the profession. These officers noted the progress that the department had made in its evolution, assessing how the department had grown its role as a professional police department. ${ }^{50}$ 
In the face of the persistent problem of not being taken seriously, RUPD officers continued to prove that they excelled in their dedication to the Rutgers community, even in the face of bodily harm. On September 28, 1997, a student and RUPD officer Leroy Washington were stabbed outside the Livingston Student Center. A fight had provoked the incident, and when Washington arrived to investigate, he was stabbed. A student, David Phillips, was charged with the stabbing, and an unaffiliated 21-year-old was also charged with assault. Almost a month later, Washington returned to duty. The incident was certainly a terrifying one for Washington, his family, and the department. He was the first RUPD officer to be stabbed in the line of duty; the incident doubtlessly brought back somber memories of the death of McGilvery in $1978 .^{51}$

In October 2006, after the RUPD had moved into its new headquarters at 55 Commercial Avenue, a memorial was held for McGilvery. A plaque was dedicated just outside the Public Safety Building in remembrance of McGilvery's service and sacrifice. The department's move to the new building, combined with its memorial for McGilvery, demonstrated that, although the RUPD was modernizing and improving, it still retained the memory of those who had faithfully served. ${ }^{52}$

The officers of the RUPD had transitioned from being security guards to being police officers over the course of the first decade or so of the department's existence. Although the rate of retention was still relatively low, the department had professionalized in a number of ways. It was becoming more diverse, officers had more tools at their disposal, and university administrators worked with the department to rectify the issue of relatively low pay. The department certainly faced growing pains, but it ended its first 25 years in a much better state that the one in which it had begun.

\section{The Evolution of the Department's Uniforms}

A police officer's uniform is his or her most immediately recognizable feature. The officers of Campus Patrol have been aware of this and the image a uniform projects throughout the organization's history. Campus Patrol's standardized uniform was, by 1966 , an olive-green uniform patterned after the New Jersey State Police uniform. This military-style uniform was in use until the department began to advocate for the use of firearms. In 1971, the United States was in the middle of the Vietnam War, which was very unpopular, especially on college campuses. Any pseudo- 
military organization, especially a police force, was at odds with an antimilitary community. Consequently, the department switched its uniforms to allay student concerns about the military and law enforcement. ${ }^{53}$

Campus Patrol went civilian in appearance, changing from a militaristic olive-drab army-style shirt with an army-style hat, leather belt, and leather shoulder strap to an academic-looking "dark grey felt hat, dark blue blazer, light blue shirt (white shirt for sergeants and up), scarlet and black Rutgers tie, light grey-blue slacks and black shoes." Ochs stated that the uniforms "reflected the changing university atmosphere in which less military type uniforms were more appropriate." These uniforms were also doubtlessly adopted to make the idea of an armed Campus Patrol more palatable to the student body. ${ }^{54}$

By September 1974, patrolmen were requesting new uniforms, along with a new name and the right to carry firearms on all shifts. The image of being academic officials with an in loco parentis role presented a dichotomy that they wanted removed from their role. The officers wanted their department to be a true law enforcement agency and hoped to finally stop straddling two different worlds to become full police officers. Their uniform transitioned from the civilian-looking uniform adopted several years prior to a more professional gray uniform. The officers wanted to be treated like "the regular police force we are." Bloustein stated that he hoped the changes would "increase public recognition of the professional status and responsibilities of our University police officers. ${ }^{\text {" } 5}$

By the late 1990s, the RUPD officers had changed to wearing navy blue uniforms. The new uniforms originally included the same triangle-shaped Rutgers Police patch on the left shoulder that the previous uniform had included, but shortly afterward that was changed to an updated patch consisting of a silhouette of New Jersey encircled by the three cities in which Rutgers has campuses, with "1766," the year of Rutgers' founding, bisected by the silhouette of New Jersey. This is the present RUPD uniform, with a slight modification to the patch.

\section{The Acquisition of Firearms}

Campus Patrol had begun in 1963 as an unarmed security force. But, even in that early era, its responsibilities were those of a law enforcement agency. For much of 1964, according to the Targum, a rumor had been circulating that Campus Patrol officers 
carried firearms. In response, Ochs stated, "We haven't asked for this, nor are we ready for it." Ochs did mention that there are dangers associated with rural campuses, in which local police would be fewer and farther between, and because of that, "in the future patrolmen on the Kilmer Campus may receive training to carry a weapon for protection purposes." This idea would become a reality as campus patrolmen began to advocate for firearms for their own protection. ${ }^{56}$

The late 1960s were a tumultuous time in America, a time during which crimes involving the use of deadly weapons increased in frequency. The effect at Rutgers was a feeling that the officers of Campus Patrol needed additional safety measures to protect themselves against the increase in violent crime. In a February 1969 Targum article, it was reported that "quietly but earnestly, Campus Patrol is seeking the power to carry guns and make arrests." The department planned on achieving this power by launching a bill through the New Jersey attorney general's office. The bill did not explicitly grant Campus Patrol officers the right to carry weapons; rather, it made the act of a college patrol officer carrying a weapon a legal possibility. Until this point in time, no college security forces in New Jersey could carry firearms. This law made it possible for Campus Patrol to truly be a law enforcement agency. ${ }^{57}$

Ochs justified the request by stating that his officers needed firearms to protect the students and themselves from outsiders, not to protect themselves from the students: "We need the powers especially to deal with non-University personnel who commit crimes on University property." Regardless of the events of 1968 on campus, Ochs was still a paternalistic protector of the students, a role that he had doubtlessly inherited from his undergraduate days and his relationship with Gross, but he also understood the responsibilities and dangers faced by Campus Patrol. ${ }^{58}$

The proposal met with some harsh resistance from the students. Many felt that the Campus Patrol should not be armed because of race issues. At Rutgers during this time, the Black Student Unity Movement, among other student groups, felt that many of the faculty and employees of the university were racist. More often than not, student opinion of Campus Patrol was not very high. One student's opinion of the department rang clear through his words when he proclaimed his thoughts on the issue: "If we gave those incompetent fools guns, they might hurt themselves." Another student felt a bit more apprehensive about issues of authority, saying, "No matter what the reason, if you give a man a gun, he can 
become a different person." Overall, most student reactions were suspicious. They felt that if Campus Patrol had existed for this long without firearms, why did it need them now? One student, who described himself as being "what leftists describe as reactionary," was in favor of patrolmen obtaining the power of arrest and the right to carry weapons. ${ }^{59}$

In particular, an incident on the new Livingston College campus highlighted some students' opinions about the operations of Campus Patrol. In March 1973, two Campus Patrol officers were charged with brutality in the arrest of two Livingston College students, Consuelo Rivera and William Hernandez. The students, both of whom were Puerto Rican, claimed that the two officers, Monica Batiuk and Lynne Englehardt, had physically and verbally assaulted them. The students had been observed stealing a table and an ashtray and were apprehended by Detective Robert Franz, who began to search Consuelo Rivera, who objected and requested that a female officer search her. According to the students, officers Batiuk and Englehardt arrived and transported the two suspects to Campus Patrol headquarters at 5 Huntington Street, where they fingerprinted, beat, and spat on them. Further, the students claimed that they were subsequently transported to the Piscataway Police headquarters, where they were charged and further assaulted by Batiuk, Englehardt, and lieutenant Homer Emmonds, while a fourth officer did nothing to stop it. The report of this event caused a massive uproar in the student body. The accounts of the conduct of the officers were from the perspective of the students who were caught stealing. Those accounts were the ones that were made public and reacted to by campus officials. ${ }^{60}$

Members of the Rutgers community, largely from Livingston, were up in arms over the incident. The demonstrators felt that the brutality had occurred because the students were Puerto Rican, and they incited racially fueled demonstrations. A group of approximately 60 students, faculty, and staff gathered in front of University Police's headquarters "carrying signs such as 'down with the pigs' and 'we will not tolerate brutality." The group then cut a rope on a flagpole, which caused the American flag to be ripped apart as it fell. The group of protestors grew to more than 100 and then marched to Old Queens and demanded to see President Bloustein, who was in Newark for the day. After several hours, they accepted that he was not there and moved to Ford Hall to plan further activity. ${ }^{61}$ 
By July 1973, the case had gone to trial in a Piscataway court. There was no physical evidence of the brutality, and the charges of simple assault against the Campus Patrol officers were dismissed. But, immediately afterward, complaints of atrocious assault and battery were signed against them. On July 26, 1973, all assault and battery charges against the officers were dismissed in the Piscataway court when Judge William H. Gazi ruled that "there was insufficient cause to send the charges to the grand jury." Meanwhile, charges of assaulting police officers and possession of 25 grams of marijuana against the two students were transferred to the grand jury and the Middlesex County prosecutor, respectively, for handling. Further, the university hearing on August 1, 1973, was unable to determine guilt or innocence in the matter. As of August 7, 1973, the four officers were reinstated because, according to David H. Dugan III, a lawyer who served as the board's hearing officer on the charges, "the board's conclusion was the legal equivalent of an innocent verdict." 62

This incident of possible police brutality demonstrated that there was a clear division between the students of Livingston Campus and the personnel of Campus Patrol. This division came out of the era of antimilitary/police feelings, which were especially prominent at Livingston. It was possible that these officers committed the crimes they were accused of. Additionally, one must consider the reliability of a source that was caught in the commission of a crime. Regardless of these factors, the Rutgers community responded negatively to the incident and took the side of the two Livingston students, which demonstrated that many in the Rutgers community had a low opinion of Campus Patrol.

In response to student concerns on the issue of arming campus patrolmen, Ochs "assured the Daily Targum that he never intended that Campus Patrol would ever carry weapons on the College Avenue campus, except when transporting University funds." Ochs knew that the process of arming Campus Patrol could not be completed all at once, and, although he felt an armed Campus Patrol would be a safer Campus Patrol, he knew that the student body would not quickly warm up to the idea. President Gross also vocalized his strong reservations about arming Campus Patrol, noting that"giving guns to people is in all cases the absolute last resort." Recalling his days as a student at Cambridge University in England, where police are unarmed, Gross stated, "I've always thought that way best." Further, Gross reassured students by stating 
that "the powers would be used for the assorted outside rascals who come to the campus from time to time, " and not students. ${ }^{63}$

Campus Patrol wanted full police powers, which included the power to arrest, carry firearms, and issue motor vehicle summonses. On September 18, 1970, the Targum reported:

The bill, No. 764, was introduced in the state senate by majority leader Harry Sears (R-Morris) at the request of Rutgers University. It passed unanimously in the senate on April 27 and in the general assembly on May 14 . The governor had refused to sign it until certain amendments were made. These amendments were made to satisfy police chief organizations in the state which had objected to the campus patrolmen being allowed to issue motor vehicle violation tickets without consent of the local police chief.

On this matter, Ochs said, "I hope it passes. It is necessary to provide proper police services for the university community." With the passage of this bill at the state level, Campus Patrol legally transitioned from a security force to a police department. But, just as before, Gross exclaimed that it would take a "great deal to convince me that guns are necessary on campus." Gross was an old-time academic who saw no need for such measures. But, as an opinion piece in the Targum pointed out, "In loco parentis is no good, campus as sanctuary is no longer valid, moratorium on outside interference is eliminated." 64

Student protests did not arise only due to race issues; they had other causes. In April 1970, antimilitary protests on campus led to the arrests of several students by the New Brunswick Police Department. Some students felt that "after murders in the student communities at Kent, Augusta, Kansas State, Berkeley, and Isle Vista, it should be no surprise that someone up there doesn't love us." Campus disruptions were occurring with a greater frequency; Rutgers had 227 bomb threats during the period from September 14, 1970, until January 7,1971 . The bomb threats were not just local occurrences; nationally there was a rise in bomb threats after a bomb exploded at Harvard. According to the Annual Report for 1969, "The national problem of increased offenses against persons and property was similar on Rutgers campuses. Of particular notice were the increases in acts of violence, such as assaults, robberies, 
vandalisms and the firebombing of a building." Across the country was observed a trend of college law enforcement agencies arming in response to events such as the 1970 shootings at Kent State. ${ }^{65}$

In this period of race riots, antimilitary protests, and bomb threats, it was absolutely necessary for Campus Patrol to become an armed force. Campus Patrol had confiscated numerous weapons on campus, weapons that were deadly and could easily overpower an unarmed officer. From firearms to knives and Molotov cocktails, officers faced very real threats from nonstudents who committed crimes on campus. ${ }^{66}$

In February 1972, Campus Patrol requested that its officers be allowed to carry firearms on certain shifts. A report was produced by the department to make this request formal. The report included a photo of various weapons that had been recently confiscated from crimes committed at Rutgers, including knives, clubs, and even guns. It concluded that "Campus Patrol serves the University as a municipal police department serves its community. Campus Policemen are trained; they are professionals in campus security." In Ochs's own words, Campus Patrol had evolved in the period since its creation "from a night watchman operation to a sophisticated and competent university police department." Ochs demonstrated this professionalism by explaining the training requirements of campus policemen, who are not commissioned by the university until they have graduated from a police school approved by the New Jersey Police Training Commission and their application has been approved by the New Jersey State Police after a thorough investigation to ensure that only quality officers are hired. The report also made the very valid point that "without permission for commissioned police officers to carry a weapon, continued recruitment of highly selected personnel is difficult" and compared Campus Patrol to law enforcement in London, which had in 1971 granted permission to carry firearms to its law enforcement officers. Ochs also described the dangers campus policemen encounter: "Criminals preying on the campus do not consider the academic community as a sanctuary off limits to them" as they once had. Further, the report set minimum requirements for campus police officers, such as minimum heights, weights, and vision and health criteria. It included a policy on firearms safety training and required officers to sign an oath to obey this policy. The report studied other campus police agencies whose officers had the power to carry firearms and found 143 colleges and universities whose police had the authority to carry firearms. ${ }^{67}$ 
By June 1972, Campus Patrol was beginning to refuse "to answer general assistance calls unless accompanied by an armed policeman." Campus Patrol had been given the power to arrest under the law passed in 1970, but without arms, many saw the new power as ineffectual, especially given the increasing level of crime on the Rutgers campus. ${ }^{68}$

Bloustein was much more open to the idea of arming the Campus Patrol than Gross had been. Although Bloustein was not as sure of the need for arming Campus Patrol as Ochs, he was convinced by the data presented by Campus Patrol reports and only asked that the Board of Governors vote on such a matter. The Board of Governors approved the limited arming of Campus Patrol on October 13, $1972 .{ }^{69}$

Ochs knew that he could not have his police officers carry firearms at all times at this early stage. The university community was simply not prepared to allow an unarmed security force to become armed full-time in one motion; rather, in the antimilitary and antipolice climate of the 1970s, it would be more appropriate to complete the transition in steps. The 1972 report indicated that "permission for Campus Police Officers to carry weapons will be under strict controls." Although officers would need to qualify on their firearms twice per year, a sidearm was not allowed to be used as a warning, drawn as a threat, or drawn for any other reason than if the officer's life or the life of another was threatened. An officer's weapon was to be carried only while on duty and to be issued as part of the briefing before an officer's tour began each shift. Additionally, in 1972 a weapon could be carried only on three types of occasions: during cash transports, on night shifts, and "when responding to calls where it is likely that there is a direct and immediate threat to personal life and safety. ${ }^{70}$

This was no longer the era of ivy-covered halls filled with elite young college students coming from wealthy white families, enrolling in small classes to learn about the liberal arts. This was an era in which college needed to reflect the needs of all Americans. If that need was not reflected, civil disobedience and violence might occur. The Rutgers community in 1972 was not small; it consisted of about 47,000 students, faculty, and staff, comparable to the population of a large town at the time. As the peace-keeping force for Rutgers, Campus Patrol needed to reflect that. But it was largely not this population that presented the biggest threat to safety on campus; it was the outsiders. Campus Patrol still had to deal with 
"non-University personnel who commit crimes on University property." 71

For the officers of Campus Patrol, being members of a partial police force was unsafe. The officers wanted to be part of a true law enforcement agency and finally stop straddling two different worlds to become full police officers. By September 1974, officers were requesting "new uniforms, a new name, and the right to carry loaded weapons 24 hours a day." They wanted the name Campus Patrol to be changed to something more professional sounding, replacement of their civilian-looking uniforms, and permission to carry their weapons on all shifts. The officers wanted to be treated like "the regular police force we are." At the time, the 89-person department had full arrest powers, the ability to give out parking citations, and uniformed officers as well as plainclothes detectives. ${ }^{72}$

A major point of contention for members of Campus Patrol was the sense of not being perceived as "real cops." According to the officers, an image of being real police officers would increase morale on the department and lead to a safer environment. The officers demonstrated, in a 1974 report, that violent crimes occurred throughout the day and not just at night. The report included an image of many dangerous weapons that had been confiscated on campus from outsiders in the two-year period from 1972 to 1974. On August 6, 1974, "about 30 Campus Patrolmen, supported by University firemen and Campus Guards, picketed Old Queens." Some of the patrolmen brought their children, who wore signs that read, "I Want Daddy Safe" and "Don't Leave Me Fatherless." 73

At that time, Campus Patrol officers kept their guns in their glove compartments during daytime shifts. The need for patrolmen to be armed 24/7 led Chief Michael Borden to make the request in the 1974 Report that "University Police Officers be authorized to carry weapons on all shifts," succinctly summed up by saying, "Unfortunately, crimes are not committed on a shift basis. There is no assurance that a serious crime will not occur during the day shift." Further, "Non-University personnel do not consider the University Officer as a police officer due to his lack of a weapon during daylight hours." The report also described the average university police officer as 33 years old, married with two children, with 45 months' service with the department, a high school graduate who had obtained 30 college credits. Additionally, 60 percent of officers were veterans. These officers were not young and inexperienced; rather, they were mature and experienced in their 
profession. They were fully capable of handling the responsibility granted to any neighboring municipal police department. ${ }^{74}$

Bloustein stated that he was against the full-time arming of Campus Patrol "until I see evidence to the contrary." Again Bloustein asked the University Senate, a universitywide deliberative body made up of students, faculty, staff, administrators, and alumni, to consider the issue. "On February 25, 1975, the Executive Committee of the Senate created the Ad Hoc Committee, chaired by Professor Ann Mari Biutrago of the Political Science Department, to study the matter and prepare and recommendation to the Senate for its consideration," and the committee held their first meeting on Friday, March 14, 1975. In February 1975, Rutgers authorized the name change from Campus Patrol to the Rutgers University Police Department and also authorized a uniform change from the civilian attire to a more professional gray uniform. Bloustein stated that he hoped the changes would "increase public recognition of the professional status and responsibilities of our University police officers. "75

After much correspondence between the committee appointed by the senate and Ochs, on May 6, 1975, the resolution adopted by the University Senate stated that it "is not opposed to the President requesting the Board of Governors to authorize 24 hour arming of the University Police, if in his independent judgment such an action is warranted, provided that such action is taken under the following conditions." The conditions for officers to carry their .38-caliber revolvers all hours of the day were that they could not carry during student demonstrations or protests, sporting events, concerts, forums, or when assigned to monitor campus eating and drinking places. Further, the senate recommended continued training and procedures for issuing and returning weapons when officers began and ended their tours. Another recommendation was that the provost of each campus designate a member of his or her staff to serve as the safety compliance officer for investigating alleged misuse of weapons, give wide public notice of that office, and report annually to the president the number and nature of complaints received by that office and on crime as a whole. The senate also recommended an emphasis on higher education for police officers. ${ }^{76}$

On May 9, 1975, the Board of Governors unanimously approved a resolution that authorized all commissioned Rutgers University police officers to carry firearms while on duty. Shortly 
thereafter, on June 4, 1975, the RUPD made an official policy on the use of firearms by its officers. The final restrictions were that weapons were not to be drawn on students unless there was an immediate threat to life, weapons were not to be used for the routine patrolling of campus eating and drinking areas, and the president could impose any administrative regulations that would be necessary to limit the risk to public safety. The RUPD now had a full repertoire of police powers officers could assume while on duty. ${ }^{77}$

The issue of RUPD officers' carrying firearms was not settled in 1975. They had won only the right to carry firearms at all times while on regular duty shifts. Municipal police officers could carry weapons at any time, even off duty. For RUPD officers, this meant that they still retained the image of not being "real cops" to some degree. On October 5, 1978, a Targum article reported that university police officers "favor carrying guns during off-duty hours." According to Robert Garrett, president of Lodge 62 of the Fraternal Order of Police, "We deal with armed robbers and rapes, yet our men are not entitled to the same protection under law while off-duty that police from other departments are entitled." Garrett stated that he felt morale was very low because of the issue and that "the UP's [University Police's] relatively low pay scale is only one reason why policemen are leaving the force to work for other municipalities." In 1977, eight commissioned police officers who had been hired, tested, and trained at the expense of the RUPD resigned to join other law enforcement agencies. ${ }^{78}$

In 1989, Rutgers Police officers began to be allowed to transport their duty firearms home from work. This marked a transition point in the abilities of RUPD officers; up until this point they had received their firearms at the beginning of each shift. The last change that brought the officers of the department onto completely equal footing with all other New Jersey municipal police departments occurred in 1991. Officers gained the power to carry their firearms off-duty and were admitted to the Police and Fire Benefits Association for their pensions. This last step in the progression of Rutgers Police from a security force to its present state as a professional law enforcement agency made it comparable to any municipal police department in New Jersey. ${ }^{79}$

The acquisition of firearms was, more than any other issue, the biggest factor in the professionalization of the Rutgers Police. Officers were trained at police academies, uniformed, and now 
armed. Criminals and the lay public alike might consider a police officer just a "rent-a-cop" or a security guard if not for his or her firearm.

\section{Conclusion}

Over the course of its 50-year history, the Rutgers University Police Department changed from an unarmed campus security force that exemplified an in loco parentis attitude toward those it existed to serve to a progressive and professional law enforcement agency with full police powers and advanced law enforcement accreditation that had not abandoned its in loco parentis responsibilities as it transformed. This trend was evident during the administration of Robert F. Ochs, director of the police and later assistant vice president of public safety, as he advocated for continued training and competitive pay for officers, while not forgetting the unique responsibilities that a university police department provides for its students.

The professionalization of the department can be measured in the expansion of the administrative structure of the department, including its authority and its jurisdiction as well as its personnel, acquisition of firearms, and transformation in uniforms. Campus Patrol transitioned to the Rutgers University Police Department by overcoming the apparent dichotomy in which it was initially unsure of its own role as either a supervisor of student life or a law enforcement agency. As it legally became a law enforcement agency, acquired the use of firearms, expanded its personnel in numbers, became more broadly representative of the diverse state population, and improved its training, the department earned a reputation and an image for professional conduct from neighboring police departments and the Rutgers community it served.

The RUPD simultaneously patrolled the urban streets and rural farms of New Brunswick, just as any municipal police department would, and also secured the university's residence halls and student facilities, a job specific to university police. The RUPD, and Rutgers as a whole, had to respond appropriately to an ever more diverse and constantly changing multiethnic, multinational, and multilingual student body that was subject to crimes ranging from robbery to domestic violence or worse but also to individual problems students might have faced. It has evolved from an unarmed security agency born out of a parking authority to a professional law enforcement agency by way of establishing a 
respected image, instilling efficacy into its officers, and building a reputation for excellence. Its 50 years of service have been a proud half-century.

\section{NOTES}

Unless otherwise stated, manuscript collections are held by Special Collections and University Archives, Rutgers University Libraries, New Brunswick, New Jersey.

The Rutgers-New Brunswick campus newspaper has been called at various times the Daily Targum, the Rutgers Daily Targum, the Rutgers Targum, and the Targum.

1. For general content, see Richard P. McCormick, Rutgers: A Bicentennial History (New Brunswick, NJ: Rutgers University Press, 1966); first quote from "McCormick Traces 'In Loco' Development on University Level," Targum, April 7, 1965, 1; second quote from Walter Carl Heyer, interview by G. Kurt Piehler (An Interview with Walter Carl Heyer for the Rutgers Oral History Archives of World War II conducted on September 12, 1996), http://oralhistory. rutgers.edu/rutgers-history/30-interviewees/interview-html-text/533heyer-william-carl; third quote from Walter Seward, interview by G. Kurt Piehler (An Interview with Walter Seward for the Rutgers Oral History Archives of World War II conducted on December 30, 1996), http://oralhistory.rutgers.edu/rutgers-history/30-interviewees/ interview-html-text/47-seward-walter. All oral history interviews conducted by the Rutgers Oral History Archives that have been cited will thereafter be referred to as simply "[Last name,] 'ROHA interview."'

2. Seward, ROHA interview; McCormick, Rutgers: A Bicentennial History, 114; The trend of New Brunswick Police coming to the Rutgers campus for crimes was one that continued well into the 1970s, and probably occurred since New Brunswick Police's founding, in 1835; reference made to a picture of a student residing in a houseboat, available at http://ruweb.rutgers.edu/timeline; "McCormick Traces."

3. McCormick, Rutgers: A Bicentennial History, 271; "McCormick Traces."

4. Ted Steinberg, Down to Earth: Nature's Role in American History (New York: Oxford University Press, 2009), 213-15; a considerable amount of correspondence was used from the papers of President Mason Welch Gross, listed as Administrative Records of Rutgers University: Office of the President: Inventory of the Records of the 
Mason Welch Gross Administration, 1936, 1945-1971 (RG 04/A16), (hereafter MWG); the quote is from a letter from Maurice T. Ayers, assistant to President Mason Gross: MWG, Box 81, Folder 12.

5. Quote from MWG letter to New Brunswick Mayor John A. Lynch, Box 81, Folder 12; other information in paragraph from MWG, Box 81, Folder 11.

6. Letter from Dean of Men to Mason Gross, MWG, Box 81, Folder 11.

7. From a letter by Maurice T. Ayers to Mason Gross, MWG, Box 81, Folder 12, and from the Annual Reports of the Rutgers Department of Public Safety (RG 42/B), Public Safety-Campus Patrol, 1963-64, 1965-69, (hereafter Annual Report, followed by the given year).

8. Quote from Robert F. Ochs, ROHA interview conducted November 24, 1997, by G. Kurt Piehler, 12; other information from Ochs, ROHA interview, 1-18, 23-26, 37; other quotes from Ochs, ROHA interview, 39; all at http://oralhistory.rutgers.edu/interviewees/1147ochs-robert.

9. Ochs, ROHA interview, 62; first quote from Ochs, ROHA interview, 62; second quote from Ochs, ROHA interview, 63.

10. Letter from Robert F. Ochs to Dr. K. R. Erfft, Rutgers vice president and treasurer, MWG, Box 81, Folder 1; Ochs, ROHA interview, 63; Annual Report, 1963-64; first quote from Home News, October 1, 1963; second and third quotes from Annual Report, 1963-64, and Home News, April 21, 1966.

11. Annual Report, 1963-64.

12. Targum, November 10, 1964, 1.

13. Quote from Targum, May 17, 1965, 1.

14. Quote from Targum, February 26, 1968, 1.

15. Annual Report, 1966, 21; Home News, April 21, 1966; Annual Report, 1965; Annual Report, 1966, 11; Annual Report, 1969, 21; Annual Report, 1970.

16. Annual Report, 1970, inside cover.

17. Student populations from Rutgers Statistics (R-Statistics) Collection, Series XIII, Box 3; the numbers are those of students at all campuses (New Brunswick and Piscataway, Newark, and Camden), undergraduate and graduate, but exclude noncredit students. Other information from miscellaneous Targum articles of 1972, and a paragraph from a 1972 report produced by the officers of Campus Patrol on carrying firearms on certain shifts titled A Report to Request That Campus Police Officers Be Permitted to Carry Weapons on Selected Posts, 5, available in the records of the director of communications at the Rutgers University Public Safety Building, (hereafter 1972 Report). Other information from Annual Report, 1970, and Annual Report, 1965; quote from Annual Report, 1970, 19.

18. Targum, April 29, 1971, 1.

19. Annual Report, 1975; Annual Report, 1978; Annual Report, 1979. 
20. Annual Report, 1979; Targum, September 13, 1983, 13.

21. Annual Report, 1982; Annual Report, 1984; Annual Report, 1985; Targum, September 13, 1983, 13, and November 16, 1982, 3, 6.

22. Ochs, ROHA interview, 76.

23. First quote from Ochs, ROHA interview, 75-76; second quote from Ochs, ROHA interview, 78.

24. Targum, November 4, 1993, 1, 4; Targum, November 8, 1993, 1; Targum, November 18, 1993, 1, 6 and November 19, 1993 1, 4; Targum, November 23, 1993 1, 10.

25. Targum, February 27, 1992, 1; Targum, April 15, 1992, 1, 4; quote from Targum, March 12, 1992, 1, 4; other information from Targum, March 23, 1992, 1, 3.

26. Targum, September 16, 1992, 1, 3; quote from Targum, December 2, 1992, 1; other information from Targum, September 15, 1992, 1, 9.

27. Quote from Targum, April 5, 1995, 1, 4; other information from Targum, April 10, 1995, 1, 6.

28. Targum, September 14, 2001, 1, 4.

29. Rutgers Focus, May 12, 2003, 3; Rutgers Focus, March 6, 2006, 1, 4; Jay Kohl, ROHA interview conducted on March 8, 2013 (not yet available online); Targum, March 20, 2006, 3.

30. Targum, October 30, 2001, 3.

31. Quote from Annual Report, 2001, 27; other information from Targum, March 21, 2005, 1, 4.

32. Kohl, ROHA interview; other information from Rutgers New Brunswick website, http://nb.rutgers.edu/about-us/campus-safety.

33. Kohl, ROHA interview.

34. Jay Kohl, "Fire Rescue and Survival Training for Officers," Campus Law Enforcement Journal 33 (2003): 8-10.

35. Ibid.

36. Information from Rutgers Social Work website, http://socialwork. rutgers.edu/CentersandPrograms/VAWC.aspx, as well as the Rutgers Violence Prevention and Victim Assistance website, http://vpva. rutgers.edu/our-mission/our-history; further information retrieved from website about Tyler Clementi, http://tylerclementi.org/tylersstory/; further information from the Standard Operating Guidelines of the Rutgers University Police Department, used with permission.

37. Information about Chief Harris from Old Dominion University news website, http://hamptonroads.com/2012/01/old-dominionhires-new-police-chief-rutgers; first quote and information from CALEA website, http://calea.org/; second quote from Rutgers Police website, http://rupd.rutgers.edu; other information from Kohl, ROHA interview.

38. Quote and information from Annual Report, 1963-64.

39. Quote from Annual Report, 1963-64. 
40. First quote from Annual Report, 1966, 14; second quote from Annual Report, 1968, 15.

41. First quote from Annual Report, 1965, 11; other information from Annual Report, 1966; second quote from Annual Report, 1965, 11.

42. Targum, October 13, 1972, 1; quote from Targum, October 13, 1972, 1; other information from Edith Lin and Barbara Raffel Price, "The Evolving Role of Women in American Policing," in Bryan Vila and Cynthia Morris, eds., The Role of Police in American Society: A Documentary History (Westport, CT: Greenwood, 1999), 240.

43. Annual Report, 1975; Annual Report, 1979; Samuel L. Williams, "Law Enforcement and Affirmative Action" in Vila and Morris, The Role of Police in American Society, 217.

44. First quote from Home News, April 27, 1973; second and third quotes from Home News, January 14, 1973; fourth quote from Home News, March 17, 1973.

45. Quotes from Targum, October 13, 1972, 1.

46. Quotes from Targum, October 9, 1978, 1.

47. Quote from Annual Report, 1985, 21.

48. Targum, October 5, 1978, 1, 16; first and second quotes from Targum, October 5, 1978, 1; third quote from Annual Report, 1978.

49. Quotes from Targum, March 26, 1998, 1, 4.

50. First quote from Targum, November 30, 1999, 1; other information from Targum, March 27, 1998, 1, 4; letter from retired Piscataway Police Lieutenant Amy Myzie to Matthew D. Knoblauch on April 2, 2013, used with written permission; Peter Pelletier, ROHA interview conducted on March 4, 2013 (not yet available online).

51. Targum, September 29, 1997, 1, 4; Targum, October 2, 1997; Targum, November 20, 1997, 1, 4.

52. Home News Tribune, October 13, 2006.

53. Richard P. McCormick, "Rutgers, The State University of New Jersey," in David Riesman and Verne A. Stadtman, Academic Transformation: Seventeen Institutions under Pressure (New York: McGraw-Hill, 1973), 271-86.

54. First quote and information in paragraph from Rutgers Photograph Collection (R-Photo), Academic and Administrative Functions, Box 15, Police, Rutgers University Parking, Security and Transportation Part 1 and Part 3 folders; second quote from Targum, September 15, 1971, 1.

55. First quote from Targum, September 12, 1974, 3; second quote from a 1975 report titled, "Report to the Senate from Ad Hoc Committee on Weapons Request," available in the records of the Director of Communications at the Rutgers University Public Safety Building; other information from a letter from Chief Michael Borden of Rutgers-New Brunswick, Captain James Hogan of Rutgers-Camden, and Captain John Upton of Rutgers-Newark to President Edward 
Bloustein, February 13, 1975, available in the records of the Director of Communications at the Rutgers University Public Safety Building.

56. Targum, November 10,1964, 1; first and second quotes from Targum, December 17, 1964, 1.

57. Quote from Targum, February 3, 1969, 1.

58. Ibid.

59. Ibid. 1, 5; other information from a letter from the dean of Rutgers-Camden to the faculty and students, April 17, 1969, in the Administrative Records of Rutgers University: Administrative Offices of the University: Rutgers University Provost and Vice President (Richard Schlatter) (RG 15/A2), Box 13, Folder 16; all three quotes from Targum, February 5, 1969, 1, 2.

60. Targum, March 28, 1973, 4.

61. Quote and information from Targum, March 28, 1973, 1, 2.

62. First quote from Home News, July 27, 1973; other information from Home News, July 19, 1973, and August 2, 1973; second quote from Home News, August 7, 1973.

63. First quote from Targum, February 6, 1969, 1; second and third quotes from Targum, February 13, 1969, 1.

64. First three quotes from Targum, September 18, 1970, 1; fourth quote from Targum, September 21, 1970, 3.

65. Targum, April 17, 1970, 2; first quote from Targum, September 21, 1970, 3; other information from Letter from Mason Gross to Rutgers Community, MWG, Box 23, Folder 4, and from Targum, November 6, 1970, 1, 6; second quote from Annual Report, 1969, 26.

66. 1972 Report.

67. First and second quotes from 1972 Report, 1 ; third quote from 1972 Report, front page; fourth quote from 1972 Report, 2; other information in paragraph from 1972 Report, 11-12.

68. Quote from Home News, June 15, 1972.

69. Home News, September 16, 1972; Minutes of the Rutgers University Board of Governors (hereafter BOG), October 13, 1973.

70. First quote and other information from 1972 Report, 2; second quote from BOG, October 13, 1972, 4.

71. Targum, February 3, 1969, 1, 5.

72. Quotes and other information from Targum, September 12, 1974, 3.

73. Ibid.

74. Annual Report, 1974; first and second quotes from Targum, September 12, 1974; third and fourth quotes from Annual Report, 1974.

75. First quote from Targum, September 18, 1974, 2; second quote from a 1975 report titled "Report to the Senate from Ad Hoc Committee on Weapons Request," available in the records of the Director of Communications at the Rutgers University Public Safety Building; other information from a letter from Chief Michael Borden of 
Rutgers-New Brunswick, Captain James Hogan of Rutgers-Camden, and Captain John Upton of Rutgers-Newark to President Edward Bloustein, February 13, 1975, available in the records of the Director of Communications at the Rutgers University Public Safety Building; second quote from Rutgers News Service, February 4, 1975; other information from Rutgers University Senate website, http://senate. rutgers.edu/.

76. Quote and other information in from a resolution adopted by the University Senate on May 6, 1975, available in the records of the Director of Communications at the Rutgers University Public Safety Building.

77. Targum, May 12, 1975, 1; memo to all Rutgers Police personnel, June 4,1975 , available in the records of the Director of Communications at the Rutgers University Public Safety Building.

78. Quotes from Targum, October 5, 1978, 1, 16.

79. Targum, March 27, 1998, 1, 4. 